\section{The Owl}

George Abbe -

State University of New York, Plattsburgh
"How difficult is faith when Christ died so long ago, and never has returned," remarked my friend. "It may be," I replied, "and yet he does come back, I have just learned."

In that intense cold of the coldest day, between sunset and dark when the west is a rose shade and quiet.lles on the palm of the air, the infinite rounded hills swing out, yet near, I climbed toward home, fighting snow to my knees, with each step praising God, with each step praying for the hunted creatures in thelr tunnelled dark. I sang, jubllant because no dog had left a trace of killing where I'd walked.

And blessing God for each lungful of hard terrible cold because it made life alert, I struggled toward my ridge and homecoming warmth, yet eager to stay on the piercing meadows of search.

And suddenly, heavy and traglc, yet burdenless as love's pain, a bird winged slowly over my path an owl, whose thoughtful flight contains the grace we cannot reach perhaps, yet strive to, with faith too cumbersome, too bound by evil's fiesh.

He flew ahead. I yearned to see his face. How easily yet remorsefully against that burning pang of twillght blue he leaned level and bowed, as though his thoughts were blessed by knowledge I could never truly reach.

And over, directly over my lonely house he sailed, and settled on the single pole that holds our wires for lights and telephone; and there, in deepening night, over naked fields where the mice burrow that 1 love and long to shield from hawk and dog, he perched, utterly lone, utterly still. I watched to catch some thrill of wakened movement, some serene lift of head. Nothing. The dark shape cold and muffled, like the pole's top, hooded and stiff, clung against western glow; darkened, blurred into the dimming, ethereal blue of icy night, till my straining eyes confused pole and bird.

He seemed to move a little only because my sight wavered from fixedness. No sound. No turn of head. No plunge to snatch pipit or mouse.

With shock, I knew Chrlst was that bird, visiting me in the warm and hooded head to watch over my dwelling while I slept under the flame-cold blue arcing the world's prayer. He broods perceptive, forming my later words; he thinks the acts that out of sleep I'll dare; his patience to conclude will break my fear, teach me when to be still, and when to curve down from dark helght in necessity's calm rush, with gentle softness as downy as God's wish. 